\title{
ALASAN DISPENSASI NIKAH USIA DINI (STUDI KASUS DI PENGADILAN AGAMA PALU )
}

\author{
Ribhan Abd. M. Aso ${ }^{1}$, Hilal Malarangan², Sahran Raden ${ }^{3}$ \\ ${ }^{1}$ Student Faculty of Shariah IAIN Palu, \\ email: ribhanabdmaso24@gmail.com \\ ${ }^{2}$ Lecturer Faculty of Shariah IAIN Palu, \\ email: hilalmalarangan1965@gmail.com \\ ${ }^{3}$ Lecturer Faculty of Shariah IAIN Palu, \\ email: sahrandn74@yahoo.com
}

\begin{abstract}
The study, entitled "Reasons for Early Marriage Dispensation (Case Study in the Palu Religious Court class IA") aims to provide an overview and explanation of the submission of an early marriage dispensation request at the 1.A Palu Religious Court and the consideration of judges in giving or rejecting requests for dispensation early marriage at the Klas 1 Palu Religious Court. This research was designed using descriptive research type, using a qualitative approach in data collection techniques. The results of the study, pointed out that the reason for the request for marriage dispensation in the Palu Religious Court was due to the fear of slander, pregnancy outside marriage, economic aspects, social aspects, and moral aspects. As for the judges' consideration in providing the determination of marriage dispensations at the hearing, the Panel of Judges used "kaida namely al-mashlahah al-mursalah". because the provisions on age restrictions and marriage dispensation are not explained in detail in the Koran, but the benefits are in line with the shariah action 'which wants to bring benefit to humans (the two brides and their families).
\end{abstract}

Keywords: Dispensation, Marriage, Religious Court of Class I.A, Judge

\begin{abstract}
Abstrak
Penelitian yang berjudul "Alasan Dispensasi Nikah Usia Dini (Studi Kasus di Pengadilan Agama Palu klas IA" ini bertujuan untuk memberikan gambaran dan penjelasan terhadap pengajuan permohonan dispensasi nikah usia dini di Pengadilan Agama Klas 1.A Palu dan pertimbangan hakim dalam memberi atau menolak permohonan dispensasi nikah usia dini di Pengadilan Agama Klas 1 Palu. Penelitian ini di desain dengan menggunakan jenis penelitian deskriptif, dengan menggunakan pendekatan kualitatif dalam teknik pengumpulan data. Hasil penelitian, menujukan bahwa alasan permohonan dispensasi nikah di Pengadilan Agama Palu dikarenakan khawatir timbulnya fitnah, hamil diluar nikah, aspek ekonomi, aspek sosial, dan aspek moral. Sedang mengenai
\end{abstract}


pertimbangan hakim dalam memberikan penetapan dispensasi nikah di persidangan, Majelis Hakim menggunakan"kaida yaitu al-mashlahah almursalah". karena ketentuan pembatasan umur dan dispensasi nikah tidak dijelaskan secara rinci di dalam al-Quran, tetapi kandungan maslahatnya sejalan dengan tindakan syara' yang ingin mewujudkan kemaslahatan bagi manusia (kedua calon mempelai beserta keluarga).

Kata Kunci : Dispensasi, Nikah, Pengadilan Agama Klas I A, Hakim

\section{A. Pendahuluan}

Peran utama dalam membentuk sebuah generasi muda yang berkualitas dalam struktur kemasyarakatan dapat dimulai dari institusi terkecil yaitu keluarga. Keluarga merupakan institusi terkecil yang dimaksudkan adalah satu komunitas yang terdiri dari suami dan istri. 1 Seorang suami dan istri awal mulanya dipertemukan dalam satu ikatan sakral yakni proses pernikahan. Kemudian, dari proses pernikahan inilah yang akan memicu adanya kehidupan yang damai dan tentram dalam keluarga. Serta dengan ikatan pernikahan, kebutuhan biologis secara sah dapat terpenuhi di antara seorang laki-laki dan perempuan, dengan kata lain hubungan suami dan istri telah ada dan terikat dengan adanya pernikahan. ${ }^{2}$ Dengan petunjuk sebagai bentuk perintah Allah swt., serta pandangan Islam melalui proses pernikahan membuktikan adanya kebesaran, ke maha kuasaan serta kasih sayang yang ditunjukkan oleh Allah swt., kepada makhluknya yakni mempertemukan dua insan yang berbeda. Penciptaan manusia tidak bisa dihindari dengan keberadaan syahwat yang telah ada sejak lahir dan dimiliki oleh manusia yang merupakan satu bentuk kecintaan terhadap lawan jenis yang membutuhkan prosedur untuk menyalurkan syahwat secara baik,

${ }^{1}$ Edwin Manumpahi, Shirley Y.V.I.Gon, Hendrik W. Pongoh, Kajian Kekerasan Dalam Rumah Tangga Terhadap Psikologi Anak Di Desa Soakonora Kecamatan Jailolo Kabupaten Halmahera Barat', E-Journal "Acta Diurna", Vol. $05 . \quad$ No. $01 \quad$ (2016) <https://ejournal.unsrat.ac.id/index.php/actadiurnakomu nikasi/article/view/11718>

${ }^{2}$ Halim Setiawan, 'Pernikahan Usia Dini Menurut Pandangan Hukum Islam', BORNEO: Journal of Islamic Studies, Vol. 3. No. 2 (2020), 60. 
sehingga kerawanan yang ditimbulkan oleh syahwat dapat dihindari. ${ }^{3}$ Umumnya, istilah pernikahan dengan akar kata "nikah" dapat diistilahkan dengan satu proses yang sakral dan tersistematis untuk menyatukan batin seorang laki-laki dan perempuan dengan diawali sebuah akad yang mengikat dari keduanya, keberadaan ini juga merupakan sunatullah yang ada dan terbukti dalam sejarah kehidupan manusia. ${ }^{4}$

Pada dasarnya keluarga terbentuk dalam perspektif Islam, ditandai dengan keberadaan ikatan perkawinan yang sah serta dianggap merupakan proses ritual suci. Sehingga proses ini memberikan isyarat kepada seorang laki-laki dan perempuan untuk mewujudkan hak-hak dan kewajiban-kewajiban barsama. Seperti yang tercantum dalam pasal $1 \mathrm{UU}$ Perkawinan No 1 tahun 1974 yang berbunyi:

Perkawinan merupakan ikatan lahir batin antara seorang pria dengan seorang wanita sebagai suami istri dengan tujuan membentuk keluarga, rumah tangga yang bahagia dan kekal berdasarkan ketuhanan Yang Maha Esa. ${ }^{5}$

Terwujudnya perkawinan sesuai cita-cita dalam perundangundangan perkawinan telah menginstruksikan dasar-dasar dalam pelaksanaan perkawinan. 6 Misalnya penetapan batas dalam usia perkawinan yang terdapat dalam pasal 7 ayat 1 dalam UUP No. 1 tahun 1974 yang menyebutkan:

Perkawinan hanya diizinkan jika pihak pria sudah mencapai 16 (enam belas) tahun. ${ }^{7}$

Sedangkan pada ayat selanjutnya menjelaskan ketika terdapat penyimpangan pasal 7 ayat (1) dapat memohon dispensasi pada Pengadilan atau pejabat lain yang dipilih oleh kedua belah pihak baik dari pihak laki-laki maupun pihak perempuan.

\footnotetext{
2017).

${ }^{3}$ Muhammad Sa'id, Armyta Dwi Pratiwi, Menikah Saja, ed. by Tree, Cet. 1 (Jakarta: QultumMedia, (Jakarta, 1985).

${ }^{4}$ Direktoral Jenderal Pembinaan Kelembagaan Agama Islam Departemen Agama, Ilmu Fiqih Jilid I

${ }^{5}$ JDIH BPK RI, Undang-Undang (UU) Tentang Perkawinan, 1974, p. 15 <https://peraturan.bpk.go.id/ >. $\quad{ }_{6}^{6}$ Direktorat Jendral Pembinaan Kelembagaan Agama Islam, Bahan Penyeluhan Hukum, (Jakarta: Depertemen Agama RI , 2010), 117.

${ }^{7}$ Depertemen Jendral Pembinaan kelembagaan Agama Islam, 119.
} 
Indonesia merupakan salah satu contoh di negara Asia Tenggara yang memiliki kesadaran yang relatif rendah untuk melaksanakan pembatasan dalam usia perkawinan yang sering tidak dipatuhi, perspektif yang menjadikan kebiasaan untuk pelaksanaan dalam perkawinan dalam usia dini akan terjadi dalam kehidupan berkeluarga. Padahal dalam UUP No. 1 tahun 1974 telah mengatur tentang batas usia dalam melangsungkan perkawinan yang lebih tegas lagi disebutkan dalam pasal 6 ayat (2):

Untuk melangsungkan perkawinan seorang yang belum mencapai umur 21 (dua puluh satu) tahun harus mendapat izin kedua orang tua. ${ }^{8}$

Pasal di atas secara fakta normatif di Indonesia telah jelas di atur, sedangkan di aturan Islam mengenai batasan dalam usia perkawinan tidak disebutkan secara spesifik. Tepatnya, Alquran mengatur ukuran batasan dalam usia perkawinan dalam pandangan isyarat kedewasaan yang diukur dalam pengistilahan baliq yang telah melekat pada setiap lakilaki maupun perempuan ketika dewasa. Hal ini yang kemudian penentuan batas usia perkawinan diharapkan sesuai dengan penempatan hukum yang akan diundangkan. ${ }^{9}$

Ungkapan yang diutarakan oleh Muhamad Fauzil Adhin dalam bukunya "Indahnya Perkawinan Dini" menyertakan dalam pandangannya terhadap usia yang dialami oleh setiap remaja terjadi antara usia 13 sampai 18 tahun. Dan tidak dipungkiri, masa remaja lebih cepat dimungkinkan terjadi pada remaja ketika dipengaruhi oleh beberapa faktor eksternal seperti adanya dukungan pendidikan yang lebih baik, faktor lingkungan sosial yang mempengaruhi pendewasaan pada masanya, serta faktor media masa audio-visual yang merupakan salah satu pemicu utama yang telah ada dalam kehidupan remaja sekitar usia 18 tahun yang mempengaruhi pola pikir remaja dalam menjalani kehidupan di masa

${ }^{9}$ Kamal Muchtar, Asas-Asas Hukum Islam Tentang Perkawinan, (Jakarta:Bulan Bintang, 1974$), 44$. 
remaja. Normalnya dan seharusnya terjadi pada pendewasaan dalam masa remaja paling lambat terjadi antara usia 22 tahun, sehingga perkawinan yang akan terjadi relatif di antara usia 20 ataukah usia 24 tahun. ${ }^{10}$

Sejak tahun 2013 hingga 2015, jumlah pasangan suami istri di bawah umur di Pengadilan Agama Palu meningkat tajam dari tahun ke tahun dan 42 permohonan pelepasan nikah dibatalkan. Artinya, kasus pergaulan bebas tidak hanya terjadi di perkotaan, akan tetapi kasus ini juga telah menyusup di pedesaan. Semakin banyak orang yang mengajukan permohonan pembebasan nikah, terutama karena sebagian besar adalah karena kehamilan di luar nikah. Jadi suka atau tidak suka kedua pasangan ini harus menikah, keharusan perkawinan yang harus dilaksanakan sebab apa yang dilakukan merupakan hal yang tidak dibenarkan dalam kehidupan bermasyarakat. Jika pembebasan pernikahan yang diberikan oleh pengadilan harus kedua pasangan penuhi, maka salah satu faktor dari pengajuan pembebasan perkawinan adalah adanya usia dalam perkawinan yang tidak memunuhi syarat dalam pengakuan perundang-undangan, khususnya yang disebutkan dalam pasal yang mengatur batas usia perkawinan pada undang-undang perkawinan.

Uraian di atas menjadikan dasar atau alasan untuk ditetapkannya dispensasi nikah di uisa dini yang dilaksanakan di Pengadilan Agama Klas 1.A. Dengan demikian, untuk memecahkan masalah tersebut tulisan ini berusaha menjawab pertanyaan yakni bagaimana pelaksanaan dispensasi nikah usia dini di Pengadilan Agama Klas 1.A Palu dan bagaimana pertimbangan hakim dalam memberi atau menolak permohonan dispensasi nikah usia dini di Pengadilan Agama Klas 1 Palu.

Maka daripada itu, penelitian ini bertujuan untuk menjelaskan serta menjawab dari dua pertanyaan yang dirumuskan dalam rumusan

${ }^{10}$ Hilma Hadikusuman, Hukum Perkawinan Indonesia Menurut Perundangan, Hukum Adat dan Hukum Agama, (Bandung: Mandar Maju, 1990), 53. 
penelitian yang di sebutkan di atas. Dan adapun penelitian ini merupakan kategori penelitian deskriptiv-kualitativ yaitu jenis penelitian yang melukiskan obyek atau peristiwa tanpa suatu maksud untuk mengambil kesimpulan-kesimpulan yang berlaku secara umum. Dalam penelitian ini dimaksudkan untuk mengetahui dan mengungkap tentang alasan dispensasi nikah di usia dini. Beberapa teknik penelitian yang digunakan dalam mengumpulkan data, yakni observasi, dan wawancara.

\section{B. Pembahasan}

\section{Penerapan Dispensasi Nikah di Pengadilan Agama Palu}

Pesan Nabi Muhammad saw., yang merupakan salah satu bentuk syariat yang dianjurkan adalah menikah. Sebab dengan menikah, manusia dapat menyalurkan syahwat dengan pasangannya yang baik dan sesuai tuntunan agama. Hal itu berlaku bagi semua makhluk hidup bukan hanya manusia saja, hewan dan tumbuhanpun memerlukan proses perkawinan untuk memenuhi kehidupannya dalam mengembangkan generasi selanjutnya. Oleh karena itu, manusia lebih diistimewakan daripada makhluk lain, mereka diatur sedemikian rupa untuk membimbing hasrat seksual agar tidak menimbulkan masalah.

Saat wawancara dengan bapak Ketua PA Palu (Drs. Khalis) menjelaskan kasus pernikahan usia dini yang memerlukan dispensasi nikah yang terjadi di Pengadilan Agama Palu. Beliau menyebutkan bahwa:

Bagi yang melaksanakan perkawinan dini bagi laki-laki yang berusia 17 tahun dan perempuan berusia 14 tahun dapat mengajukan permohonan dispensasi nikah ke Pengadilan Agama Palu. Jika memenuhi persyaratan tersebut. Pasangan yang akan menikah pada 2013 sampai 2014, umumnya dianggap pasangan yang ingin menikah saat usia muda. Ketika didaftarkan ke kantor Pengadilan Agama Palu, saat persyaratan pernikahan diverifikasi oleh pejabat Otoritas. Usianya baru 17 tahun bagi laki-laki, serta 14 tahun bagi usia perempuan. Kebanyakan pengajuan permohonan pembebasan nikah di Pengadilan Agama Palu karena alasan ekonomi, budaya, adat dan paksaan pihak orang tua. Sampai parahnya disebabkan karena kehamilan di luar nikah.

Adapun hasil wawancara dengan panitra Pengadilan Agama Palu

(Drs H. Sutarman, SH), bapak menyatakan dalam wawancaranya: 
Dispensasi nikah di Pengdilan Agama Palu berdasarkan penelitian yang penulis lakukan, pelaksanaan dispensasi nikah ini termaksuk perkara yang di periksa dan putus secara Voluntair. Maka dispensasi nikah di Pengdilan Agama Palu ini maksimal 2 (dua) bulan sudah putus, sendangkan perkara dispensasi nikah yang diputus di Pengdilan Agama Palu terhitung 2013 ada 8 (Delapan) perkara yang diputus, tahun 2014 ada 14 (Empatbals) perkara yang diputus dan pada tahun 2015 mengalami lonjakan yang sangat tinggi 20 (dua puluh ) perkara dispensasinikah yang diputus. ${ }^{11}$

Di atas merupakan dua pernyataan yang dihimpun dalam hasil wawancara pada penelitian. Pada penelitian juga menyediakan beberapa tabel yang mengelompokkan kasus dispensasi nikah yang terjadi di Pengadilan Agama Palu sejak tahun 2013 sampai tahun 2015. Berikut di bawah ini adalah tabel yang dimaksud:

Tabel

Dispensasi Nikah Usia Dini

di Pengadilan Agama Palu Tahun 2013

\begin{tabular}{|c|c|c|c|c|c|}
\hline \multirow{2}{*}{ No } & \multirow[b]{2}{*}{ No. Perkara } & \multirow{2}{*}{$\begin{array}{c}\text { Pemoho } \\
n\end{array}$} & \multicolumn{2}{|c|}{ Nama Pasangan } & \multirow{2}{*}{$\begin{array}{c}\text { Alasan } \\
\text { Permohon } \\
\text { an }\end{array}$} \\
\hline & & & Suami & Istri & \\
\hline 1. & $\begin{array}{c}\text { 010/Pdt.P/2013/PA. } \\
\mathrm{Pa}\end{array}$ & $\begin{array}{l}\text { Purwan } \\
\text { di }\end{array}$ & $\begin{array}{c}\text { Ahmad } \\
\text { Jiron Bin } \\
\text { Hardi (23 } \\
\text { Tahun) }\end{array}$ & $\begin{array}{c}\text { Siti } \\
\text { Zarwati } \\
\text { Binti (15 } \\
\text { tahun } 4 \\
\text { bulan) }\end{array}$ & $\begin{array}{l}\text { Khawatir } \\
\text { Timbulnya } \\
\text { fitna }\end{array}$ \\
\hline 2. & $\begin{array}{c}\text { 013/Pdt.P/2013/PA. } \\
\text { Pal }\end{array}$ & $\underset{n}{\text { Muslimi }}$ & $\begin{array}{c}\text { Wasman } \\
\text { Binti } \\
\text { Susman } \\
\text { (20 } \\
\text { tahun) }\end{array}$ & $\begin{array}{c}\text { Rokhimat } \\
\text { ul Amalia } \\
\text { Binti } \\
\text { Ngadiono } \\
\text { (15 tahun } \\
3 \text { bulan) } \\
\text { Dewi }\end{array}$ & $\begin{array}{c}\text { Hamil } 4 \\
\text { bulan }\end{array}$ \\
\hline 3. & $\begin{array}{c}\text { 014/Pdt.P/2014/PA. } \\
\text { Pal }\end{array}$ & $\begin{array}{c}\text { Karyant } \\
\text { o } \\
\text { (Kakak } \\
\text { Dewi) }\end{array}$ & $\begin{array}{l}\text { Dadang } \\
\text { Setiawan } \\
\text { bin } \\
\text { Susman( } \\
21 \text { tahun) }\end{array}$ & $\begin{array}{l}\text { Sulistia } \\
\text { Fiana } \\
\text { Binti } \\
\text { Harley } \\
\text { (15 tahun } \\
4 \text { bulan) }\end{array}$ & $\begin{array}{c}\text { Hamil } 4 \\
\text { bulan }\end{array}$ \\
\hline 4. & $\begin{array}{l}\text { 017Pdt.P/2013PA.P } \\
\text { al }\end{array}$ & $\begin{array}{c}\text { Sulistia } \\
\text { Fiana } \\
\text { Misdi }\end{array}$ & $\begin{array}{c}\text { Akhamad } \\
\text { Wakhid } \\
\text { Bin Sahri } \\
\text { (19 } \\
\text { tahun) }\end{array}$ & $\begin{array}{l}\text { Istiana } \\
\text { binti } \\
\text { Misdi (15 } \\
\text { tahun } 3 \\
\text { bulan) }\end{array}$ & $\begin{array}{l}\text { Khawatir } \\
\text { Timbulnya } \\
\text { fitna }\end{array}$ \\
\hline 5. & $\begin{array}{c}\text { 018/Pdt.P/2013/PA. } \\
\text { Pal }\end{array}$ & $\begin{array}{c}\text { Miadi } \\
\text { Nurcholi }\end{array}$ & $\begin{array}{l}\text { Jatno } \\
\text { suprato }\end{array}$ & $\begin{array}{l}\text { Linda } \\
\text { Noviana }\end{array}$ & $\begin{array}{l}\text { Khawatir } \\
\text { Timbulnya }\end{array}$ \\
\hline
\end{tabular}

${ }^{11} \mathrm{H}$. Sutarman Panitra Pengadilan Agama Palu wawan cara dengan di ruangan panitera pada tanggal 26 Mei 2016 


\begin{tabular}{|c|c|c|c|c|c|}
\hline 6. & $\begin{array}{c}\text { 019/Pdt.P/2013/PA. } \\
\text { Pal }\end{array}$ & Muslihin & $\begin{array}{c}\text { bin } \\
\text { Ngaturi } \\
(19 \\
\text { tahun) } \\
\text { Arif saifu } \\
\text { Aman Bin } \\
\text { Muslihin } \\
\text { (17 } \\
\text { tahun2 } \\
\text { bulan) }\end{array}$ & $\begin{array}{c}\text { Binti } \\
\text { Miadi } \\
\text { Nurcholis } \\
\\
\text { Nani } \\
\text { Yuliani } \\
\text { Binti } \\
\text { Sulyadi } \\
\text { (16 } \\
\text { tahun) }\end{array}$ & Hamil \\
\hline 7. & $\begin{array}{c}\text { 020Pdt.P/2013PA.P } \\
\text { al }\end{array}$ & $\begin{array}{l}\text { Sabern } \\
\quad 0\end{array}$ & $\begin{array}{l}\text { Fatukur } \\
\text { Rosidin } \\
\text { Bin } \\
\text { Sabero } \\
\text { (17 tahun } \\
9 \text { bulan }\end{array}$ & $\begin{array}{l}\text { Supiatin } \\
\text { Binti } \\
\text { Sukari } \\
\text { Aglis } \\
\text { Setiaono } \\
\text { (17 } \\
\text { tahun) }\end{array}$ & Hamil \\
\hline 8. & $\begin{array}{c}\text { 023/Pdt.P/2013/PA. } \\
\text { Pal }\end{array}$ & Prayogo & $\begin{array}{c}\text { Jefri } \\
\text { Ganita } \\
\text { Bin } \\
\text { Prayogo } \\
\text { (18 tahun } \\
2 \text { bulan) }\end{array}$ & $\begin{array}{c}\text { Delia } \\
\text { Prasetya } \\
\text { ni Binti } \\
\text { Aglis } \\
\text { Setiono } \\
\text { (17 } \\
\text { tahun) }\end{array}$ & $\begin{array}{l}\text { Hamil } 5 \\
\text { bulan }\end{array}$ \\
\hline \multicolumn{6}{|c|}{ Sumber data: Register Pengadilan Agama Palu } \\
\hline \multirow{3}{*}{ No } & \multicolumn{5}{|c|}{$\begin{array}{c}\text { Tabel } \\
\text { Dispensasi Nikah Usia Dini } \\
\text { di Pengadilan Agama Palu Tahun } 2014\end{array}$} \\
\hline & \multirow[b]{2}{*}{ No. Perkara } & \multirow{2}{*}{$\begin{array}{c}\text { Pemoho } \\
n\end{array}$} & \multicolumn{2}{|c|}{ Nama Pasangan } & Alasan \\
\hline & & & Suami & Istri & $\begin{array}{c}\text { Permohon } \\
\text { an }\end{array}$ \\
\hline 1. & $\begin{array}{c}\text { 005/Pdt.P/2014/PA } \\
. \mathrm{Pa}\end{array}$ & Supriono & $\begin{array}{c}\text { Akhmad } \\
\text { Wakhid } \\
\text { Bini } \\
\text { Jamsari } \\
\text { (24 Tahun) }\end{array}$ & $\begin{array}{l}\text { Ayu Sitti } \\
\text { Lestari } \\
\text { Binti } \\
\text { Supriono } \\
\text { (15 tahun } \\
6 \text { bulan) }\end{array}$ & $\begin{array}{l}\text { Khawatir } \\
\text { Timbulnya } \\
\text { fitna }\end{array}$ \\
\hline 2. & $\begin{array}{c}\text { 007/Pdt.P/2014/PA } \\
\text {.Pal }\end{array}$ & $\begin{array}{c}\text { Heri } \\
\text { Wiyono }\end{array}$ & $\begin{array}{c}\text { Fuji } \\
\text { Nurkholiq } \\
\text { BinNgadira } \\
\text { n }\end{array}$ & $\begin{array}{l}\text { Eva Dilla } \\
\text { Sagita } \\
\text { Binti Heri } \\
\text { Wiyono }\end{array}$ & $\begin{array}{l}\text { Hamil } 4 \\
\text { bulan }\end{array}$ \\
\hline 3. & $\begin{array}{c}\text { 008/Pdt.P/2014/PA } \\
\text {.Pal }\end{array}$ & $\begin{array}{l}\text { Kariyant } \\
\text { o (kakak } \\
\text { Fajar } \\
\text { Rudianto }\end{array}$ & $\begin{array}{c}\text { Fajar } \\
\text { Rudianto } \\
\text { Bin Ratno } \\
\text { (18 tahun } 2 \\
\text { bulan }\end{array}$ & $\begin{array}{c}\text { Anik } \\
\text { Anjar } \\
\text { Wati Binti } \\
\text { Ngamuri } \\
\text { (16 } \\
\text { tahun) }\end{array}$ & Hamil \\
\hline 4. & $\begin{array}{c}\text { 005/Pdt.P/2014/PA } \\
\text {.Pal }\end{array}$ & Kasmani & $\begin{array}{l}\text { Ahmad Nur } \\
\text { Kholidin } \\
\text { Bin } \\
\text { Kasmani }\end{array}$ & $\begin{array}{l}\text { Ika } \\
\text { Setiana } \\
\text { Binti } \\
\text { Suparma }\end{array}$ & Hamil \\
\hline
\end{tabular}




\begin{tabular}{|c|c|c|c|c|c|}
\hline & & & & $\begin{array}{l}\mathrm{n}(17 \\
\text { tahun })\end{array}$ & \\
\hline 5. & $\begin{array}{c}\text { 006/Pdt.P/2014/PA } \\
\text {.Pal }\end{array}$ & Kasipin & $\begin{array}{c}\text { Riko } \\
\text { Kiscahyon } \\
\text { o (17 tahun } \\
8 \text { bulan })\end{array}$ & $\begin{array}{c}\text { Fitriani } \\
\text { Binti } \\
\text { Kamali } \\
(17 \\
\text { tahun) }\end{array}$ & $\begin{array}{l}\text { Hamil } 4 \\
\text { bulan }\end{array}$ \\
\hline 6. & $\begin{array}{c}\text { 010/Pdt.P/2014/PA } \\
\text {.Pal }\end{array}$ & $\begin{array}{l}\text { Mat } \\
\text { Djudi }\end{array}$ & $\begin{array}{c}\text { Sobirin Bin } \\
\text { Mat Djudi } \\
\text { (18 tahun } 5 \\
\text { bulan) }\end{array}$ & $\begin{array}{l}\text { Rokiyati } \\
\text { Minti } \\
\text { Nurmin } \\
\text { (16 } \\
\text { tahun) } \\
\text { Eka }\end{array}$ & $\begin{array}{l}\text { Hamil } 5 \\
\text { bulan }\end{array}$ \\
\hline 7. & $\begin{array}{c}\text { 020/Pdt.P/2014/PA } \\
\text {.Pal }\end{array}$ & Ismun & $\begin{array}{c}\text { Anif Sultoni } \\
\text { Bin Ismu } \\
\text { (16 tahun } 4 \\
\text { bulan) }\end{array}$ & $\begin{array}{c}\text { Fawitri } \\
\text { Ningsih } \\
\text { Binti } \\
\text { Slamet } \\
\text { suri }\end{array}$ & Hamil \\
\hline 8. & $\begin{array}{c}\text { 017/Pdt.P/2014/PA } \\
\text {.Pal }\end{array}$ & Samijin & $\begin{array}{c}\text { Suraji Bin } \\
\text { Samijin (17 } \\
\text { tahun } 3 \\
\text { bulan) }\end{array}$ & $\begin{array}{l}\text { Eka Sari } \\
\text { RAhmaw } \\
\text { ati (17 } \\
\text { tahun) }\end{array}$ & Hamil \\
\hline 9. & $\begin{array}{c}\text { 018/Pdt.P/2014/PA } \\
\text {.Pal }\end{array}$ & $\begin{array}{l}\text { Muhyon } \\
0\end{array}$ & $\begin{array}{c}\text { Zeni Andi } \\
\text { Sulistiayaw } \\
\text { an (23 } \\
\text { tahun) }\end{array}$ & $\begin{array}{l}\text { Epli } \\
\text { Marlina } \\
\text { Binti } \\
\text { Muhyono } \\
\text { (15 tahun } \\
6 \text { bulan) }\end{array}$ & $\begin{array}{c}\text { Khawatir } \\
\text { Timbulnya } \\
\text { fitna }\end{array}$ \\
\hline $\begin{array}{l}10 \\
.\end{array}$ & $\begin{array}{c}\text { 020/Pdt.P/2014/PA } \\
\text {.Pal }\end{array}$ & $\begin{array}{l}\text { Hartanto } \\
\text { (Kakek } \\
\text { Imatu } \\
\text { Najya) }\end{array}$ & $\begin{array}{l}\text { Mugiono } \\
\text { Bin Sutikno } \\
\text { (20 tahun) }\end{array}$ & $\begin{array}{l}\text { Imatu } \\
\text { Najwa } \\
\text { Binti } \\
\text { Imbron } \\
\text { (15 tahun } \\
6 \text { bulan) }\end{array}$ & $\begin{array}{l}\text { Hamil } 1 \\
\text { bulan }\end{array}$ \\
\hline 11 & $\begin{array}{c}\text { 022/Pdt.P/2014/PA } \\
\text {.Pal }\end{array}$ & Maryo & $\begin{array}{c}\text { Ridlo } \\
\text { Purnomo } \\
\text { Bin } \\
\text { Sumijan } \\
\text { (19 tahun) }\end{array}$ & $\begin{array}{l}\text { Nursaanti } \\
\text { Hidaya } \\
\text { Binti } \\
\text { Maryo } \\
\text { (15 tahun } \\
6 \text { bulan) }\end{array}$ & Hamil \\
\hline 12 & $\begin{array}{c}\text { 005/Pdt.P/2014/PA } \\
\text {.Pal }\end{array}$ & $\begin{array}{c}\text { Nur } \\
\text { Aidah } \\
\text { (Kak } \\
\text { Ahmad } \\
\text { Nurholidi } \\
\text { n) }\end{array}$ & $\begin{array}{c}\text { Ahmad } \\
\text { Nurkholidin } \\
\text { Bin } \\
\text { Kasmani } \\
\text { (16 tahun } \\
10 \text { bulan) }\end{array}$ & $\begin{array}{c}\text { Ika } \\
\text { Setiana } \\
\text { Binti } \\
\text { Suparma } \\
\text { n (16 } \\
\text { tahun) } \\
\text { Eka }\end{array}$ & $\begin{array}{l}\text { Hamil } 3 \\
\text { bulan }\end{array}$ \\
\hline 13 & $\begin{array}{c}\text { 030/Pdt.P/2014/PA } \\
\text {.Pal }\end{array}$ & Zainudin & $\begin{array}{l}\text { Sugeng } \\
\text { Prasetio } \\
\text { Bin } \\
\text { Zainudin }\end{array}$ & $\begin{array}{l}\text { Setiawati } \\
\text { Binti } \\
\text { Sukeri } \\
(16\end{array}$ & $\begin{array}{l}\text { Hamil } 5 \\
\text { bulan }\end{array}$ \\
\hline 14 & 057/Pdt.P/2014/PA & Abdul & Aditiya & lka & Hamil \\
\hline
\end{tabular}




\begin{tabular}{|c|c|c|c|c|c|}
\hline . & .Pal & Fatah & $\begin{array}{c}\text { Bagus } \\
\text { Darmawan } \\
\text { Bin Abdul } \\
\text { Fatah (18 } \\
\text { tahun } 6 \\
\text { bulan) }\end{array}$ & $\begin{array}{cc}\text { lestiana } \\
\text { Binti } \\
3 & \text { Hardi }(17 \\
\text { tahun })\end{array}$ & \\
\hline \multicolumn{6}{|c|}{ Sumber data: Register Pengadilan Agama Palu Klas 1.A } \\
\hline \multicolumn{6}{|c|}{$\begin{array}{c}\text { Tabel } \\
\text { Dispensasi Nikah Usia Dini } \\
\text { di Pengadilan Agama Palu Tahun } 2015\end{array}$} \\
\hline $\mathrm{N}$ & & & Nama & Jasangan & Alasan \\
\hline 0. & No. Perkara & on & Suami & Istri & $\begin{array}{c}\text { Permoho } \\
\text { nan }\end{array}$ \\
\hline 1. & $\begin{array}{c}\text { 002/Pdt.P/2015/PA } \\
. \mathrm{Pa}\end{array}$ & $\begin{array}{l}\text { Darmin } \\
\text { to }\end{array}$ & $\begin{array}{l}\text { Rais Bin } \\
\text { Romdon } \\
\quad(21 \\
\text { tahun })\end{array}$ & $\begin{array}{l}\text { Listiani Binti } \\
\text { Darminto } \\
\text { (15 tahun } 5 \\
\text { bulan) }\end{array}$ & $\begin{array}{l}\text { Khawatir } \\
\text { Timbulny } \\
\text { a fitna }\end{array}$ \\
\hline 2. & $\begin{array}{c}\text { 010/Pdt.P/2015/PA } \\
\text {.Pal }\end{array}$ & $\begin{array}{c}\text { Ngadio } \\
\text { no }\end{array}$ & $\begin{array}{l}\text { Atdholari } \\
\text { s Bin } \\
\text { Sukirno } \\
(21 \\
\text { tahun }) \\
\text { Ahmad }\end{array}$ & $\begin{array}{l}\text { Rokhimatul } \\
\text { Amalia Binti } \\
\text { Ngadiono } \\
\text { (15 tahun } 3 \\
\text { bulan) }\end{array}$ & Hamil \\
\hline 3. & $\begin{array}{c}\text { 011/Pdt.P/2015/PA } \\
\text {.Pal }\end{array}$ & $\begin{array}{l}\text { Suwan } \\
\text { di }\end{array}$ & $\begin{array}{l}\text { Muhlizin } \\
\text { Bin } \\
\text { Suwandi } \\
\text { (18 tahun } \\
3 \text { bulan) }\end{array}$ & $\begin{array}{l}\text { Siti Asih } \\
\text { Kumaero } \\
\text { (14 tahun) }\end{array}$ & $\begin{array}{c}\text { Khawatir } \\
\text { Timbulny } \\
\text { a fitna }\end{array}$ \\
\hline 4. & $\begin{array}{c}\text { 0020/Pdt.P/2015/P } \\
\text { A.Pal }\end{array}$ & $\underset{\mathrm{d}}{\operatorname{Achma}}$ & $\begin{array}{l}\text { Sofyan } \\
\text { Bin } \\
\text { Achmad } \\
\text { (18 tahun } \\
2 \text { bulan) } \\
\text { Johan }\end{array}$ & $\begin{array}{l}\text { Zipora Anita } \\
\text { Ayucristiani } \\
\text { Binti Trimos } \\
\text { (17 tahun) }\end{array}$ & $\begin{array}{l}\text { Hamil } 2 \\
\text { bulan }\end{array}$ \\
\hline 5. & $\begin{array}{c}\text { 0010/Pdt.P/2015/P } \\
\text { A.Pal }\end{array}$ & Supari & $\begin{array}{l}\text { Untung } \\
\text { Bin } \\
\text { Supari } \\
\text { (17 tahun } \\
10 \text { bulan) }\end{array}$ & $\begin{array}{l}\text { Apri Vitri } \\
\text { AStuti Binti } \\
\text { tugimin (17 } \\
\text { tahun) }\end{array}$ & $\begin{array}{l}\text { Hamil } 4 \\
\text { bulan }\end{array}$ \\
\hline 6. & $\begin{array}{c}\text { 0023/Pdt.P/2015/P } \\
\text { A.Pal }\end{array}$ & $\begin{array}{l}\text { Wahyu } \\
\text { Prabow } \\
\quad \text { o }\end{array}$ & $\begin{array}{l}\text { Anggit } \\
\text { Indra Bin } \\
\text { Wahyu } \\
\text { prabowo } \\
\text { (18 tahun } \\
4 \text { bulan) }\end{array}$ & $\begin{array}{l}\text { Khomatul } \\
\text { Nikma (18 } \\
\text { tahun) }\end{array}$ & Hamil \\
\hline 7. & $\begin{array}{c}\text { 0002/Pdt.P/2015/P } \\
\text { A.Pal }\end{array}$ & Supari & $\begin{array}{l}\text { Untung } \\
\text { Bin } \\
\text { Supari } \\
\text { (17 tahun } \\
7 \text { bulan) }\end{array}$ & $\begin{array}{l}\text { Nur Arifah } \\
\text { Binti } \\
\text { Suramin }(17 \\
\quad \text { tahun) }\end{array}$ & Hamil \\
\hline 8. & 0030/Pdt.P/2015/P & Ahmad & Eka & Sofyan & Khawatir \\
\hline
\end{tabular}




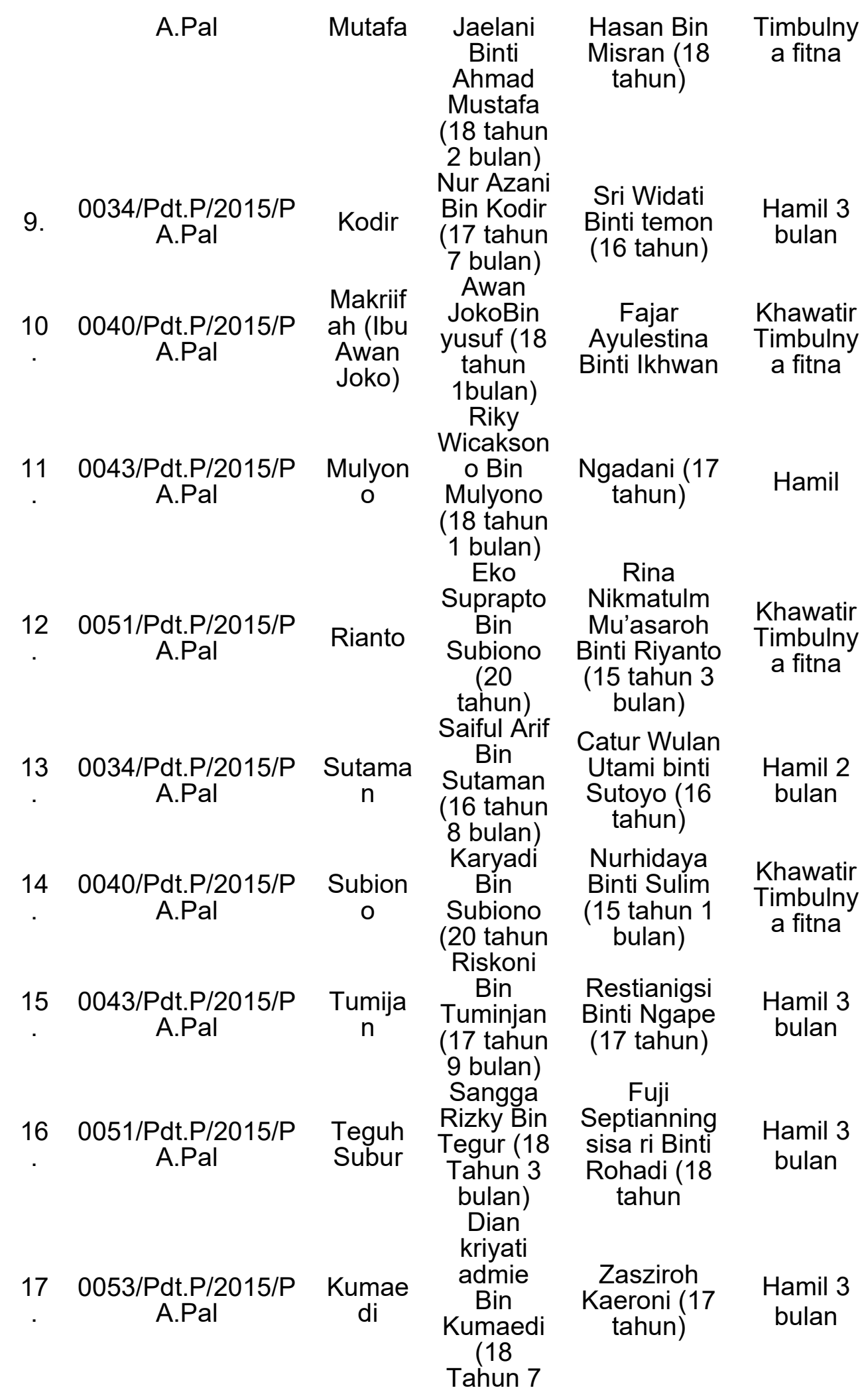




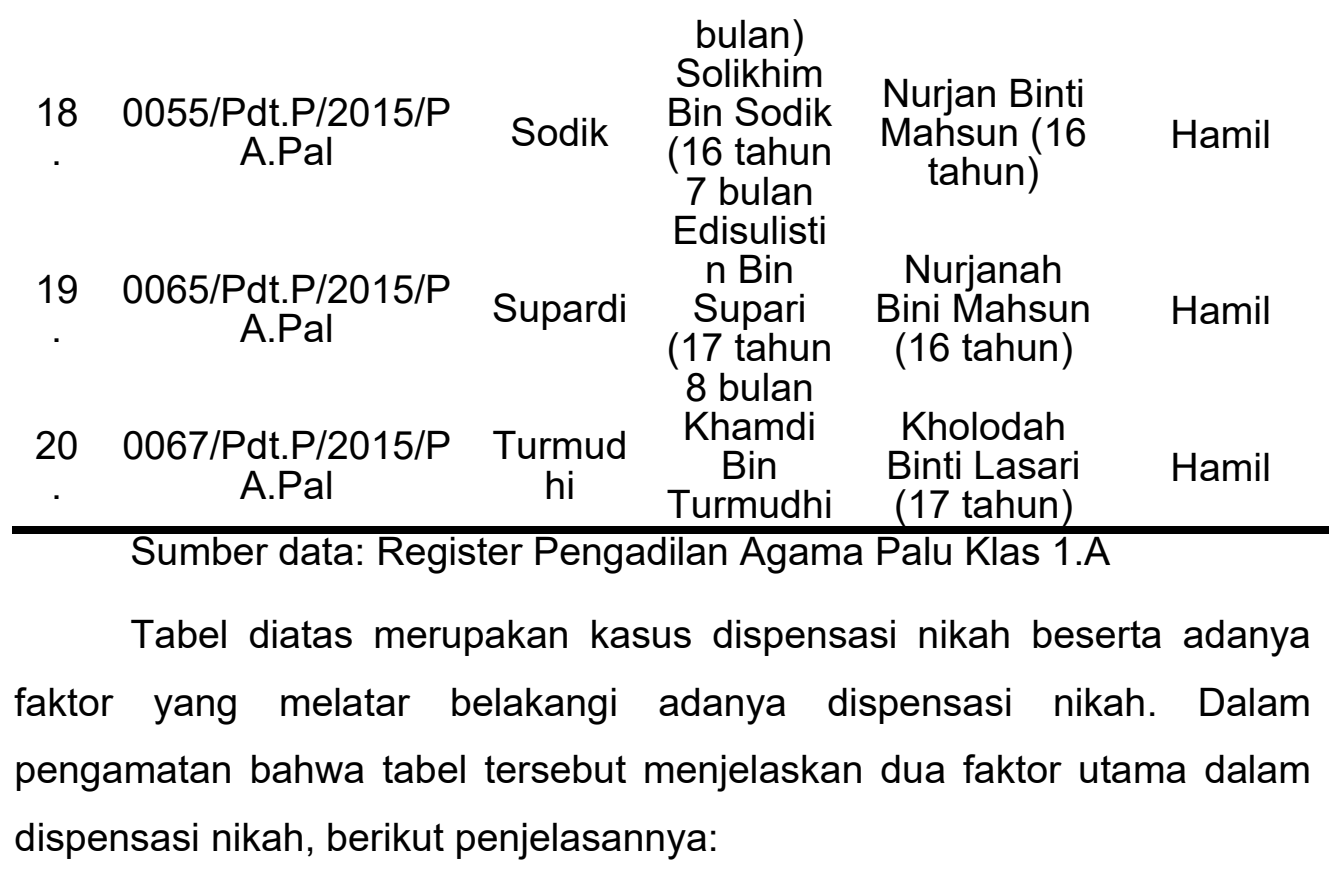

a. Khawatir timbulnya fitnah

Pengadilan Agama Palu telah memberlakukan dispensasi nikah dengan alasan karena takut timbulnya fitnah yang akan terjadi pada anak. Sehingga orang tua juga khawatir kepada anak-anaknya sudah lama berpacaran dan sering bertemu, akan terjadi hal-hal yang tidak diinginkan. Sebagian besar wilayah Provinsi Sulawesi Tengah adalah pedesaan, dan pedesaan juga, beberapa anak yang memiliki pola pikir yang pemikiran layaknya orang dewasa sering berkumpul bersama, akibatnya anak tersebut akan menjadi sasaran pembicaraan tetangga dengan kehidupan pergaulan yang dijalani. Bahan fitnah yang terdengar sampai ke telinga orang tua, akan mengakibatkan orang tua mengambil sebuah upaya untuk menikahkan anaknya dengan tujuan bentuk fitnah tersebut tidak akan terdengar lagi di keluarga anak laki- laki maupun perempuan.

b. Hamil diluar nikah

Wawancara dengan Hakim Pengadilan Agama Palu Drs. Khalis mengatakan:

Pergaulan bebas dan pengaruh-pengaruh media elektronik yang semakin canggi sehingga untuk mengakses pornografi dan porno aksi semakin mudah hal ini yang paling mempengaruhi terjadinya 
hamil diluar nikah. Hamil diluar nikah merupakan faktor yang mendominasi terjadinya dispensasi nikah, karena dispensasi nikah dijadikan jambatan untuk menutupi aib keluarga dan juga untuk mencega kerusakan yang lebih parah jika tidak dinikahkan, pasangan yang hamil diluar ini berdasrkan pada tabel diatas diajukan oleh pihak laki-laki sedang selisih umur mereka hannya berkisar pada hitungan bulan mulai dari 2 bulan-1 tahun. ${ }^{12}$

\section{Pertimbangan dalam Pemberian Dispensasi Nikah di \\ Pengadilan Agama Palu}

Sebagai pelaksana keadilan, hakim bersifat independen dan berwibawa dalam menjalankan tugasnya, hakim tidak terpengaruh oleh institusi manapun dalam menjalankan tugasnya, karena hakim hanya tunduk pada hukum dan keadilan. Ada banyak kasus yang diatur oleh undang-undang, dan hakim harus menggali dan menemukan hukum sebanyak mungkin, dan menggunakan bukti yang ada untuk menganalisis dan menerapkannya dalam kasus tersebut.

Keputusan yang diambil oleh hakim harus mempertimbangkan fakta hukum di persidangan. Hal yang mengatur tentang eksepsi perkawinan merupakan aturan yang mengatur batas usia orang yang diizinkan untuk menikah. Pasal 7 undang-undang No.1 Tahun 1974, menyatakan bahwa bila seseorang (yang beragama Islam) belum mencapai usia minimum, dapat mengajukan dispensasi nikah kepada Pengadilan Agama. Aturan lain yang mengatur dispensasi nikah adalah pasal 15 Kompilasi Hukum, Islam yang maksudnya sama dengan pasal 7 Undang-undang No. 1 tahun 1974. Namun, kedua aturan tersebut tidak rinci menyebutkan alasannya. Sehingga Hakim di Pengadilan Agama Palu memiliki beberapa pertimbangan dalam memutuskan pemberian dispensasi perkawinan kepada pemohon. Diantaranya, pertimbangan hakim berdasarkan bukti-bukti dan mengadirkan adanya saksi-saksi. Berdasarkan pada analisis penulis, hakim di Pengadilan Agama Palu mengambil beberapa pertimbangan dalam mengambil keputusan untuk memberikan dispensasi nikah, yaitu pertimbangan hakim berdasarkan

\footnotetext{
${ }^{12}$ Drs. Khalis hakim Pengadilan Agama Palu wawancara di ruangan khusus diskusi Kantor Pengadilan Agama Pada tanggal 20 Juni tahun 2016
} 
peraturan yang berlaku daripada pertimbangan hakim dalam mengambil keputusan. Keputusan harus sesuai dengan hukum yang berlaku. Oleh karena itu, adanya persyaratan dalam dispensasi nikah yang perlu ada seperti:

a. Foto copy Surat Kelahiran atas nama anak pemohon yang dikeluarkan Kepala Desa atau Kelurahan.

b. Surat Pemberitahuan Penolakan Melangsungkan Pernikahan (Model N-9) yang dikeluarkan oleh Kantor Urusan Agama.

Penentuan dispensasi nikah dalam putusan hakim dikaitkan harus berdasarkan alat bukti dan keterangan saksi, kemudian keterangan saksisaksi tersebut dibandingkan dengan keterangan pemohon, biasanya diberikan oleh saksi-saksi yang hadirkan dalam persidangan. Biasanya hakim yang meminta keterangan dari dua saksi sebagai pendukung dalam pemberian dispensasi nikah dua. Memperbolehkan permohonana dispensasi nikah Hakim juga berdasarkan pada syarita Islam. Adapun yang biasa digunakan hakim dalam perkara dispensasi nikah Hakim mengunakan dasar kaidah:

Artinya:

Menolak kerusakan didahulukan daripada mendapatkan/menarik kemaslahatan.

Penggunaan kaidah ini terjadi apabila dalam suatu perkara terlihat adanya manfaat, namun di situ juga terdapat adanya kemafsadatan (kerusakan), maka haruslah didahulukan menghilangkan kemafsadatan ini. Karena kemafsadatan dapat meluas dan menjalar ke mana-mana, sehingga akan mengakibatkan kerusakan yang lebih besar lagi. ${ }^{13}$

Islam sangat tegas dan tidak mengenal kelonggaran dalam kemaksiatan (penyakit sosial), karena jika kemaksiatan dibiarkan menyebar, berarti sama halnya akan menjerumuskan ke dalam kehinaan. Sedangkan kemaksiatan itu ibarat kanker ganas yang apabila tidak segera

${ }^{13}$ Himpunan Putusan Majelis Tarjih Muhammadiyah 
diobati akan mengorogoti tubuh manusia sampai mati oleh karena itu pencegahan bersikap proaktif .dan prefentif (pecegahan) dalam memerangi kemaksiatan tersebut. ${ }^{14}$ Untuk menghilangkan kerusakan yang seharusnya tidak menimbulkan kerusakan lain, maka harus memilih kerusakan yang relatif lebih kecil dari kerusakan yang sudah terjadi. Menurut hakim, kerugiannya adalah jika tidak menikah, maka terjadinya kejahatan dan perkawinan yang tidak wajar akan meningkat, sehingga mengganggu prosedur hukum selanjutnya atau mengubah hak hukum anak yang lahir sesuai dengan hukum.

Setelah diketahui alasannya, dispensasi nikah di Pengadilan Agama Palu terutama kehamilan di luar nikah merupakan penyebab terbesar dalam pemberian dispensasi nikah, jadi upaya ini untuk meminimalisir adanya rasa malu yang akan tumbuh dalam kehidupan mereka yang hamil sebelum menikah. Selain itu, kurang mampu menikah menurut undang-undang perkawinan, itulah sebabnya perkawinan sering dijadikan alternatif untuk menutupi masalah yang dialami. Solusi dari masalah sosial berikutnya adalah menikahi gadis hamil terlebih dahulu untuk menutupi rasa malu.

Tabel Penyebab Dispensasi Nikah Tahun 2013-2015

\begin{tabular}{|l|l|l|}
\hline No. & Penyebab & Jumlah \\
\hline 1. & $\begin{array}{l}\text { Kehendak orang } \\
\text { tua }\end{array}$ & 11 Pasangan suami istri \\
\hline 2. & Hamil diluar nikah & 31 Pasangan suami istri \\
\hline
\end{tabular}

Menurut penelitian ini, hakim di Pengadilan Agama Palu menyetujui permohonan dispensasi nikah dan mempertimbangkan kemanfaatannya. Sebab jika tidak menyetujui, hakim khawatir perkawinan yang dilanjutkan akan menghasilkan anak dengan garis keturunan yang tidak teratur.

\footnotetext{
${ }^{14}$ Dudung Abdul Rohman, Mengembangkan Etika Berumah Tangga Menjadi Moralitas Banggsa Menuju Pandangan Al-Qur'an, (Bandung: Nuansa Aulia, 2006), 136.
} 
Selanjutnya, ketika hakim memberikan dispensasi perkawinan untuk dikabulkan, karena mengingat perempuan yang hamil tanpa suami akan dihina dan ditolak oleh masyarakat, maka setidaknya hakim selalu mengabulkan permintaan dispensasi nikah..

\section{Efek Dispensasi Nikah Usia Dini Terhadap Keberadaan}

\section{Pernikahan di Wilayah Hukum Pengadilan Agama Palu.}

Perkawinan adalah ikatan lahir batin antara laki-laki dan perempuan sebagai suami istri dengan tujuan untuk membangun keluarga yang bahagia dan kekal berdasarkan Tuhan Yang Maha Esa. Dalam Islam, orang yang ingin menikah dibagi menjadi tiga bagian dalam pembagian pensyariatan, yaitu jika dia sudah perlu menikah, dikatakan bahwa orang tersebut wajib menikah. Jika dia tidak bisa atau belum mampu untuk menikah, maka hukumnya makruh. Apabila orang yang berniat untuk menikah, namun menikah hanya menyakitinya maka hukum pernikahan adalah haram. Akan tetapi hukum pernikahan secara primitif diperbolehkan, sebagaimana firman Allah swt., dalam Q.S An-Nur [24]: 32

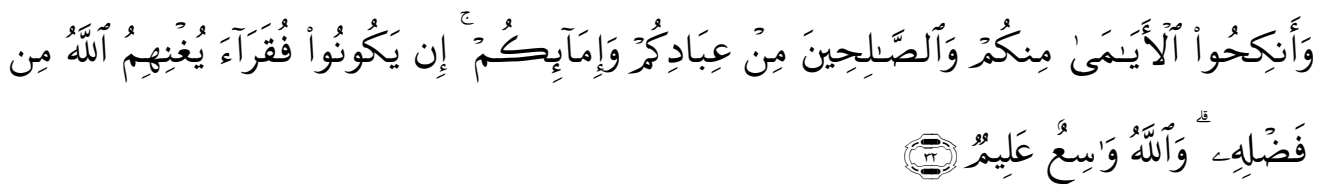

Terjemahnya:

Dan kawinkanlah orang-orang yang sedirian diantara kamu, dan orang-orang yang layak (berkawin) dari hamba-hamba sahayamu yang lelaki dan hamba-hamba sahayamu yang perempuan. jika mereka miskin Allah akan memampukan mereka dengan kurniaNya. dan Allah Maha Luas (pemberian-Nya) lagi Maha mengetahui. ${ }^{15}$

Kata Baa'ah artinya: bekal, yang artinya rumah (tempat tinggal), tetapi tidak bagi orang yang tidak memiliki bekal, maka dianjurkan untuk berpuasa. Sebab puasa dapat menjaga diri dan menghindari munkar mata dan alat kelamin. Secara teknis, Islam tidak menentukan batas usia untuk menikah, tetapi Islam membatasi kemampuan orang-orang yang direkomendasikan untuk menikah. Menurut Imam Syafi' I memandang

${ }^{15} \mathrm{Al}$-Qur'an dan Terjemahannya (Mushaf Fatimah), (Jakarta: PT. Insan Media Pustaka, 2012), 354. 
nikah itu sendiri berarti hal yang disunahkan, namun menurut Imam Ahmad, nikah itu wajib bagi orang yang merasa tidak bisa menghindari perbuatan munkar (zina). Jadi, Undang-undang Perkawinan menetapkan bahwa batas usia untuk menikah adalah 19 tahun untuk pria dan 16 tahun untuk wanita. Jika usia kurang dari ketentuan Undang-Undang Perkawinan, dapat mengajukan permohonan dispensasi nikah di Pengadilan agama setempat..

Pengadilan Agama Klas IA Palu merupakan badan hukum di Provinsi Sulawesi Tengah yang kewenangannya harus memberikan hak dispensasi bagi pasangan suami istri yang usianya lebih muda dari peraturan yang berlaku saat ini untuk dibebaskan dari perkawinan. Pada dasarnya, penulis menilai bahwa dispensasi tersebut tidak mempengaruhi adanya perkawinan, karena usia mereka yang relatif mudah, dan usia pernikahan yang relatif mudah, yang juga bermuara pada perceraian dalam undang-undang itu sendiri, yang memuat asas sukar dalam perceraian. Sementara itu pada wilayah hukum di lingkungan Pengadilan Agama Palu, keluarga yang dibangun oleh pasangan suami istri yang mendapatkan persetujuan dispensasi nikah telah membawa dampak negatif, yaitu karena seringnya terjadi pertengkaran, kecemburuan, dan sikap keras suami terhadap pasanganya yang hingga menimbulkan kekerasan dalam rumah tangga. Minimnya cara istri dalam mendidik dan mengajar anak serta pengetahuannya dalam mengasuh anak pada akhirnya akan mengakibatkan kelemahan psikis, kemiskinan mental dan fisik anak. Ketika stabil secara emosional, si istri membiarkan banyak pertengkaran dalam keluarga.

Pertengkaran dalam keluarga salah satu akibatnya adalah kedewasaan seseorang dalam menata rumah tangga belum terpenuhi pada pernikahan. Jadi, ukuran yang dikatakan seseorang telah dewasa bukan hanya dilihat pada berapa usianya, namun unsur lain yang dapat diperkirakan untuk mendukung tingkat kedewasaan seseorang yang terlihat secara mental yakni keluarga, dengan siapa saat bergaul, tingkat 
kecerdasan, sampai tingkat pendidikan. Semakin matang dalam kedewasaan orang semakin bisa menyeimbangkan emosi dan proporsinya, orang yang suka berkelahi sering kali naif dan tidak bisa menahan emosinya.

Dispensasi nikah yang dapat ditemukan dalam kehidupan keluarga beberapa pasangan suami-istri juga berdampak positif. Karena maksud dalam sebuah pernikahan bagi pasangan suami-istri adalah untuk mencegah perzinahan dan kemaksiatan di antara keduanya, dimulai dari niat yang suci, sehingga kehidupan keluarga tidak mudah terpengaruh oleh masalah yang ada, karena rasa tanggung jawab dan kasih sayang antar anggota keluarga, maka mudah untuk membentuk keluarga yang sakinah mawaddah warrahmah. Kematangan jiwa raga secara jasmani dan rohani, serta kematangan ekonomi, maka harus ada sebelum menikah. Jika tidak maka rumah tangga yang dibangun akan mudah terkena berbagai masalah yang muncul dalam kehidupan berumah tangga, sehingga masa depan menjadi redup.

Hukum yang dimaksudkan dalam perundang-undangan juga memperhatikan prinsip-prinsip tertentu yang berkaitan dengan pernikahan. Mengenai prinsip-prinsip yang menjadi asas tersebut adalah:

a Arah dalam perkawinan pada hakikatnya adalah untuk membentuk keluarga yang bahagia dan kekal, karena suami istri perlu saling tolong menolong dan melengkapi, agar setiap orang dapat mengembangkan kepribadiannya masing-masing, membentuk dan memperoleh kebahagiaan lahir dan batin.

b Undang-undang mengenai perkawinan telah menegaskan, perkawinan adalah sah jika dilakukan menurut agama dan kepercayaan masing-masing, selain itu setiap perkawinan harus dicatatkan sesuai dengan ketentuan hukum yang berlaku.

c Hukum perkawinan menuntut monogami, dan suami dapat menikahi lebih dari satu orang hanya jika orang yang bersangkutan menghendakinya. 
d Undang-undang perkawinan menekankan pada prinsip bahwa calon pasangan harus matang jasmani dan rohani sebelum dapat menikah, agar dapat mewujudkan tujuan perkawinan dengan benar, terlepas dari perceraian, dan memiliki keturunan yang sehat dan sehat.

e Karena maksud dari perkawinan adalah untuk menata keluarga yang selalu bahagia dan sejahtera, maka aturan menekankan pada asas perceraian yang sulit.

f Dalam kehidupan keluarga dan masyarakat, hak dan status istri seimbang dengan hak status suami, sehingga segala sesuatu dalam keluarga dapat dirundingkan bersama oleh suami istri..

Oleh karena itu, mengamalkan pernikahan pada dasarnya bukan hanya untuk kesenangan atau kebahagiaan sementara, juga bukan hanya untuk memenuhi kebutuhan fisik, tetapi untuk kebahagiaan abadi, serta harus bertanggung jawab atas bahtera rumah tangga di pengadilan Allah swt. Jika perceraian telah terjadi dalam perkawinan, maka perkawinan tidak dapat lagi untuk dipertahankan. Pada hakikatnya perceraian dalam pernikahan merupakan perbuatan yang dibenci oleh Allah swt. Karena itu, kedewasaan dalam sebuah perkawinan sangat mendukung pada pasangan yang ingin membentuk keluarga yang dicita-citakan oleh undang-undang, dan syariat Islam.

\section{Penutup}

Bagian penutup dapat diambil kesimpulan bahwa dispensasi nikah bagi anak di bawah umur merupakan bentuk perlindungan terhadap anak dan anak yang belum lahir. Dispensasi nikah yang disetujui oleh Pengadilan Agama Palu klas I.A bermaksud untuk menghindari stres atau tekanan, dan kelahiran anakpun menjadi kekuatan hukum, sehingga anak tidak malu menjadi bahan pencemaran nama baik. Sudah sepatutnya hakim mengabulkan permohonan dispensasi nikah bagi anak usia dini pada persoalan hamil di luar nikah, faktor ekonomi. Sebab aturan dalam Undang-Undang Perkawinan yang memperbolehkan seorang anak di usia 
dini dapat melangsungkan pernikahan, dengan mempertimbangkan kepentingan terbaik bagi anak. Dispensasi nikah sendiri merupakan bentuk tanggung jawab orang tua terhadap anak yang telah mengalami "kecelakaan".

\section{Daftar Pustaka}

Al-Qur'an dan Terjemahannya (Mushaf Fatimah), Jakarta: PT. Insan Media Pustaka, 2012

Abdulrahman, Kitab 'ala Mazahib al-Arba'ah t.tp:Dat Ihya al Turas alArabi, juz IV,1986.

Abdurrahman, Kompilasi Hukum Islam Di Indonesia, edisi I, Jakarta: Akademika Presindo 1992.

Adhim, Mohammad Fauzil, Indahnya Perkawinan Dini, Jakarta: Gema Insani, 2002.

Aliy, As'ad Fathul Mu'in, Jilid 2, terj. Moh. Tolcha Mansor, Kudus: Menara, 1998.

Al-Qura'an dan Terjemahannya, Jakarta: Percetakan Dana Karya,2002.

Bin Muhamad Taqiyyudin, Abu Bakr, Kifayatul akhyar, Juz II Jakarta:Dar AlKutub

Depertemen Agama RI Perwakilan Jawah Tengah, Undang-undang Perkawinan, Semarang: CV.Alawiyah, 1974.

Depertemen RI, Kompilasi Hukum Islam Di Indonesia, Jakarta:Direktorat Jendral Pembinaan Kelembagaan Agama Islam, 1997.

Direktoral Jenderal Pembinaan Kelembagaan Agama Islam Departemen Agama, Ilmu Fiqih Jilid I, Jakarta, 1985.

Direktorat Jendral Pembinaan Kelembagaan Agama Islam Depertemen Agama, Bahaya Penyuluhan Hukum, Jakarta: Depertemen Agama RI, 2001.

Direktorat Jendral Pembinaan Kelebagaan Agama Islam, Kompilasi Hukum Islam di Indonesia, Jakarta; Depertemen Agama Republik Indonesia, 2000.

Faridl, Miftah,150 Masalah Nikah Keluarga, Jakarta:Gema insani,1999. 
Fathurrahman, Djamil, Metode Ijtihad Majelis Tarjih Muhammadiyah, Jakarta: Logos, 1995.

Ghozali Abdu Rahman, Fikih Munakahat Cet II, Jakarta; Prenada Media Grop, ;2003.

Ghozali, Abdu Rahman, Fiqh Munakahat, Cet IV, Jakarta: Prenada Media group, 2010.

H. Aminuddin, Abidin Slamet, Fiqih Munakahat, cet 1, Bandung: Putaka Setia, 1999.

Hadi, Amirul, dan Haryono, Metodologi Penelitian Pendidikan, Cet. I t.t., CV. Pustaka Setia, 1998.

Hadikusuma, Hilman, Hukum Perkawinan Indonesia, Bandung: Mandar Maju1990.

Hadikusuman, Hilman, Hukum Perkawinan Indonesi Menurut Perundangan, Hukum Adat dan Hukum Agama, Bandung: Mandar Maju, 1990.

Hakim Rahmat, Hukum Perkawinan Islam, cet 1, Bandung: Pustaka Setia

Hasbi, As-Shiddieqy, Falsafah Hukum Islam, cet, IV;Jakarta: PT Bulan Bintang, 1990.

http://Www,Google.Co,Id/\#HI=ld\&Source=Hp\&Biw=1360\&Bih=607\&O=Sy arat +Dispensasi+Nikah\&Aq $=F \& A q i=\& O q=\& F p=972920 f 419 c e 278$ di Akses tangal 21Desember 2015

Jawad, Mughniyah Muhamad, Fikih Lima Mazhab, Basrie Press, tkp

JDIH BPK RI, Undang-Undang (UU) Tentang Perkawinan, 1974, https://peraturan.bpk.go.id/

Mahkama Agung RI, Pedoman Pelaksanaan Tugas dan Administrasi, Buku II,

Manumpahi, Edwin, Shirley Y.V.I.Gon, Hendrik W. Pongoh, 'Kajian Kekerasan Dalam Rumah Tangga Terhadap Psikologi Anak Di Desa Soakonora Kecamatan Jailolo Kabupaten Halmahera Barat', E-Journal "Acta Diurna", Vol. 05. No. 01, 2016. $<$ https://ejournal.unsrat.ac.id/index.php/actadiurnakomunikasi/article /view/11718>

Mohamad Daud, Ali H., Hukum Islam Pengantar IImu Hukum dan tata Hukum Islam di Indonesia Jakarta: P.T Raja Grafindo,19990.

Muchtar, Kamal, Asas-Asas Hukum Islam Tentang Perkawinan, Jakarta: Bulan Bintang,1974.

Mughniyah, Muhamad Jawad, Fikih Lima Mazhab, Basrie Press, tkp.,t.t. 
Mujieb, M, Abdul, dkk, Kamus Istilah Fikih, Jakarta: Pustaka Firdaus, 1994.

Mukti, Arto, Pratek Perkara Perdata Pengadilan Agama, Yogyakart: Pustaka Pelajar, 2007.

Nasaruddin Latif, Sutan Marajo, Problematika Seputar keluarga dan Rumah Tangga, Bandung: Pustaka Hiddayah, 2001.

Rasyidi, Lili, Hukum Perkawinan dan perceraian di Malasysia dan Indonesia, Cet I, Bandung; RemajA Rosdakarya;1991.

Rofiq, Ahmad, Hukum Islam Di Indonesia, Jakarta: PT Raja Grafindo Pesada, 1998.

Rohman Dudung, Abdul, Mengembangkan Etika Berumah Tangga Menjadi Moralitas Banggsa Menuju Pandangan Al-Qur'an, Bandung: Nuansa Aulia, 2006.

Rohman, Abdul Dudung. Mengembamgkan Etika Berumah Tangga Menjaga Moralitas Bangsa Menuju Pandangan Al-qur'an, Bandung: Nuansa Aulia, 2006.

Sa'id, Muhammad, Armyta Dwi Pratiwi, Menikah Saja, ed. by Tree, Cet. 1, Jakarta: QultumMedia, 2017.

Sabiqh, Syyid, Figh al-Sunnah, Bandung: PT. Al-Ma'uf, 1987.

Saleh, Fiqih Sehari-hari, Jakarta: Gema Insani,2006

Salim Bin Smeer, Safinatun Najah, ter. Abdul Kadir Aljufri. Surabya: Mutiarallmu. 1994.

Setiawan, Halim, 'Pernikahan Usia Dini Menurut Pandangan Hukum Islam', BORNEO: Journal of Islamic Studies, Vol. 3. No. 2, 2020.

Shomad, Abd, Penormaan Prinsip Syariah Dalam Hukum Indonesia, cet II, Madura: Kencana Prenada Media Group, 2012.

Singarimbun, Masri, Effendi Setva, Metode Penelitian Survei, Jakarta: LP3S, 1989.

Sitompul, Anwar, Kewenangan Dan Tatat Cara Berperkara di Pengadilan Agama, Bandung: Armico, 2001.

Sudarsono, Hukum Perkawinan Nasional, Jakarta: Rineka Cipta, 2005.

Suharsimi, Arikanto, Prosedur Penelitian IImiah, Suatu pendekatan praktek, Ed.II; Cet.IX, Jakarta, Rineka Cipta,1993.

Suparmono, Gatot, Segi-segi Hukum Hubungan Luar Nikah, Jakarta: Djambatan, 1998. 
Surakhmad, Winarmo, Dasar da Tehnik Research, Pengantar Metodologi IImiah, Ed. VI, Bandung : Tarsito, 1978.

Syarifuddin, Amir, Hukum Perkawinan Islam di Indonesia: Antara Fiqih Munakahat dan Undang-Undang Perkawinan, Jakarta: Kencana, 2007.

Syarifudin, Amir, Hukum Perkwinana Indonesia, cet II, Jakarta: Penada Mulia, 2007.

Tjokrowisastro, Soedjito, Pedoman Penyelengaraan Catatan Sipil, Jakarta: Bina Aksara, 1985.

Ukasyah, Athibi, Wanita Mengapa Merosot Akhlaknya, Jakarta: Gema Insani,1998.

Undang-Undang Republik Indonesia No. 1 Tahun 1997 Tentang Perkawinan dan Kompilasi hukum Islam, Citra umbara, Bandung, cetakan III tahun 2009.

Warson Munawir, Al-Munawwir Ahmad, Kamus Arab-Indonesia, Ed.II; Surabaya: Pustaka Progresif;1997.

Zahra, Muhamad Abu, al-ahwal al-syakhsiyyah Qohirah: Dar al-fikar al‘arabi , 1957. 